Aleksandra Kuzior,

Ph.D., Silesian University of Technology, Poland

ORCID ID, 0000-0001-9764-5320

email: aleksandra.kuzior@pols.pl

Michalene Grebski,

Ph.D., Colorado Mesa University, USA

ORCID ID, 0000-0002-3487-4473

email:mgrebski@coloradomesa.edu

Wes Grebski,

Ph.D., The Pennsylvania State University, USA

ORCID ID, 0000-0002-4684-7608

email:wxg3@psu.edu

Correspondence author: aleksandra.kuzior@polsl.pl

\title{
MARKETING OF AN ACADEMIC PROGRAM: CASE STUDY OF AN ENGINEERING PROGRAM
}

Abstract. The main purpose of this research was the development of an effective marketing strategy for academic programs. The nature of academic programs has significantly changed. The curriculum at those programs as well as the methods for recruiting students were very traditional and rigid. In recent decades many private universities were created and started competing with established public universities. At the same time, public universities started competing among themselves. Recently many people view university education as an investment which provides a return in the form of well-paid employment after the completion of their formal education. The recruitment strategy needs to be adjusted to the changing conditions. Every academic program is trying to compete for the best highlymotivated high school students. Academic programs are operating in a similar mode to traditional businesses by selling educational services. The article presents a marketing approach to offering educational services in universities using the example of an Engineering Program at The Pennsylvania State University Hazleton (USA). The authors, using the case study method, place their considerations in a broader context of issues related to the marketing and communication strategy of universities. They indicate the need to use the 7-element marketing mix using the broader context of relationship marketing and feedback as well as building the brand of the university to skillfully meet the challenges of the dynamically developing world and the constantly evolving labour market, while not giving up the intellectualization of the educational processes and shaping the personality of the students. The methodology used in this study was a case study of the marketing of an Engineering program at The Pennsylvania State University (USA). This is a public university successfully competing with many private universities in the United States (USA). A theoretical analysis of the marketing strategy based on the best and most effective practices is being presented in the article. The paper also contains practical suggestions and recommendations that can be used by both private and state universities.

Keywords: higher education, marketing communication, marketing mix, marketing strategy, relationship marketing, service marketing.

Introduction. According to some authors, the development of marketing dates back to the 18th century (Fullerton, 1988). R. Bartels (1988) dates the development of marketing to the beginning of the 20th century. J.E. Hagerty (1936) reports that «marketing» as a university-taught subject was first introduced in 1909 at the Harvard School of Business Administration, and the first book with the term «marketing» in its title was written by L. D. H. Weld (1915). In the literature on the subject, we also find

Cite as: Kuzior, A., Grebski, M., \& Grebski, W., (2021). Marketing of an Academic Program: Case Study of an Engineering Program. Marketing and Management of Innovations, 1, 56-64.

56 http://doi.org/10.21272/mmi.2021.1-05 
positions in which the beginnings of marketing are related to the period after the Second World War (Webster, 2002; Brownlie and Saren, 1992). F. E. Webster (2002) believes that the marketing of the 1920s was not really marketing in the strict sense, but only managerial activities related to modelling or stimulating demand, aimed at increasing sales. Many managers still confuse marketing with sales and sales management. Properly understood marketing is about understanding customers and their needs as well as a strategic approach. In «The Practice of Management» P. Drucker (1954) argued that marketing cannot be treated as a separate management function, but rather as an integral part of the entire business seen from the customer's point of view. An important element of Drucker's approach to management is responsibility towards an individual client and responsibility towards society as a whole (Kuzior, 2007). The 1970s and 1980s saw the development of service marketing (Kozielski, 2013), which is important from the point of view of the topic of marketing services in higher education discussed in this article.

Literature Review. Interest in marketing services in higher education developed to varying degrees in different countries. It depended on the level of development of higher education in a given country, the degree of privatization or the degree of bureaucracy in higher education, competition on the educational market, educational offer, demographic factors, economic factors, including the possibility of financing the use of marketing tools and other issues affecting the interest in potential university applicants. In Poland, the market of educational services, including the market of higher education services, began to take shape only in the 1990s (Antczak, 2011). The rapid development of the Polish educational market meant that marketing of educational services, as a specialized segment of marketing in general, has even become a subject taught at university. The popularity of issues related to the marketing of educational services in Poland is also characterized by a large number of scientific articles in this field. According to Google Scholar, this issue appears in 12,800 publications in Polish, although compared to English-language publications it is rather small. In English, Google Scholar indicates 4,090,000 results for the query «marketing of educational services», and 3,800,000 results for the query «marketing in higher education» (as at 1 of January 2021). Recent years have brought interest in the marketing of educational services not only of commercial entities. Higher education institutions financed from state budget subsidies must also use marketing instruments to effectively compete in the educational market. More extensive studies on the marketing of educational services and the market of educational services in various countries (including Poland, the Russian Federation, Serbia, Spain, Great Britain, Canada, Hong Kong, Italy, the Czech Republic), taken from different perspectives, can be found in publications Brkanlic et al. (2020), Nureev et al. (2020), Smørvik and Vespestad (2020). Knight (2019), Fajčíkova and Urbancova (2019), Fantauzzi et al. (2019), James and Derrick (2019), Guilbault (2018). Bolat and O'Sullivan, (2017), Ivy (2008), Hayes (2007). Often, higher education is perceived in the broader paradigm of sustainable development (Lopes et al., 2019; Kuzior, 2010), which may have a positive impact on the image of a university and translate into better competitiveness in the education market. Relationship marketing is also gaining more and more important in promoting higher education (Trullas et al., 2018; Guilbault, 2016; Helgesen, 2008). Besides, social media and the Internet are gaining more and more important in the marketing of educational services (Mazurek et al., 2019; Rosmala, 2012). For almost two decades, the most popular approach has been the use of marketing mix instruments (Brkanlic et al., 2020; Ndofirepi et al., 2020; Ivy, 2008; Kustin, 2004). In well-prepared universities to operate on the educational market, marketing strategies are developed based on the marketing mix tools. However, even this approach is not sufficient. To gain a distinctive position in the educational market, it is necessary to build the image of the university in line with its mission and vision but to adapt the educational and research aspect according to the needs of the target market. Therefore, holistic integrated actions are needed, based on strategic thinking, which is necessary for the marketing management of the organization and building the university brand (Celoch, 2015). This, of course, requires a certain amount of time and money. Shaping the brand of a university requires creating a differentiating advantage (providing a product and service that will be 
more satisfactory for a candidate for studies than the competition's offer). The brand cannot only be created. It must also be backed up by real opportunities to fulfil the promises made to potential candidates. An indispensable element of building a brand is the promotion and consolidation of positive associations with universities (Penar фртв Szczepańska-Woszczyna, 2011). This requires the use of a 7-element marketing mix instrumentation (product, price, promotion, distribution, personnel, material certificate and the process of providing services (Pabian, 2008). The key element is the promotion based on the appropriate implementation of the marketing communication system, including all necessary elements, such as advertising, personal sales, supplementary promotion and public relations (PR) activities include contacts with the mass media, conferences, publications, visualizing offers, organizing «open doors», participation in educational fairs, as well as university website and presence on social networks (Celoch, 2015) A comprehensive, not fragmentary approach, is important.

Methodology and research methods. The authors of the research used a qualitative method - a case study. The case study in management sciences is defined as an empirical inference about a contemporary phenomenon in its natural context. The method allows you to answer research questions «how?» (e.g., something is organized) and «why?» (e.g., why certain actions are taken) and allows for a thorough understanding of the phenomenon (Wojcik, 2013). In scientific research using the case study, the researcher refers to theoretical constructs related to the discussed phenomena, but it is essential to deal with the area of empirical facts. Such a clash of theory and empathy leads to the development of science. In the presented research, the authors used an idiographic approach, characteristic of the method used, characterized by «methodological eclecticism», which ensures cognitive and pragmatic effectiveness while maintaining the postulate of methodological triangulation (Matejun, 2011). For the Engineering program at The Pennsylvania State University (Hazleton, PA USA), a comprehensive approach was adopted based on observation and research, analysis of internal documentation, web content analysis, statistical data and other available source material.

The analysis of a marketing strategy for academic programs was described based on the marketing of an Engineering program at Penn State Hazleton (Hazleton, PA USA). Marketing for other academic programs can be different. The Pennsylvania State University (PSU) is a public university receiving a subsidy from the State of Pennsylvania. The subsidy which is received from the State is only $7 \%$ of the operating cost. Historically that percentage was much higher. A subsidy at the level of $7 \%$ means that $93 \%$ of the operating cost is coming from students' tuition. Therefore, tuition at (PSU) is comparable to tuition at the private institutions (where $100 \%$ of the budget comes from the students' tuition. At present (20202021), Penn State tuition and fees are $\$ 15,216 /$ yr. (estimation) at Penn State Commonwealth Campuses (Penn State Planning to Freeze, 2020-21). If the student is living on the campus, the cost of living (including room, meals and miscellaneous costs which vary by individual and academic program of study) $\$ 13,410$ $\$ 16,632 / y r$. at Penn State Commonwealth Campuses. Therefore, the total cost for students is $\$ 28,752$ $\$ 31,830 / y r$ at Penn State Commonwealth Campus.

Engineering with an Alternative Energy and Power Generation Option is a four-year program. This is under the assumption that the student comes academically well-prepared for the required courses. Very often, students need to take remedial courses which extend the duration of the program to 4.5 years or even 5 years. If the student is academically well-prepared and graduates within four years, the total cost (tuition, fees, room, meals and miscellaneous costs) is approximately $\$ 120,000$. In addition to the $\$ 120,000$ investment on behalf of the student, there is a missed opportunity cost because, during the fouryears, students could be working and generating income.

Financial aid for students is limited except for military veterans. Military veterans are individuals who have served four years of active duty. After being discharged from the military, veterans can receive tuition reimbursement for four years at the educational institution (public or private) that they have selected. Military veterans also receive a small stipend for the purchase of textbooks and other required supplies. 
Veterans' Administration (VA) through the GI Bill and other education benefits' programs help Veterans, service members, and their qualified family members with needs like identifying a school or training program and paying the tuition as well as getting career counselling (VA Education and Training Benefits, 2020; Information for Military Families and Veterans, 2020; Education Benefits and Financial Aid, 2020).

Financial aid for traditional students is limited and most students rely on loans to pay their tuition as well as living expenses during the duration of the academic program. Nationwide almost two-thirds of students take out loans to pay for college. At Penn State Hazleton, approximately $73 \%$ of students took out student loans averaging $\$ 6,122 / y r$. or $\$ 24,288$ over the four years. In the United States (USA) 45 million borrowers owed nearly $\$ 1.6$ trillion in student loan debt. USA student-loan debt is now the secondhighest consumer debt (Friedman, 2020).

What Who is the competition? There are private universities in Pennsylvania that offer academic programs including ABET-accredited Engineering programs. The cost of tuition at private universities is slightly higher than tuition at The Pennsylvania State University (PSU). However, private universities have more flexibility in offering tuition discounts to better-prepared students, so that they would be attracted into their academic programs. The Pennsylvania State University, a public university sponsored by state funding, does not have that flexibility in offering discounted tuition. Private universities do not have to follow any procedures related to purchasing equipment and supplies. The Pennsylvania State University follow state guidelines related to purchasing equipment and supplies. All major purchases involve a bidding process which is cumbersome and increases the cost factor. Private universities hire independent professional recruiters who are being paid for every prospect student brought to the program. The Pennsylvania State University has only an Admissions Department. The Admissions Department can visit different high schools to promote the program, but they do not get financial benefits for every student recruited. Professional recruiters from private universities are more proactive and aggressive in their recruitment strategies. The Pennsylvania State University needs to compete with many private colleges. Considering the cost of operating a public university is higher than the cost of operating private colleges, the tuition which is paid by the students is comparable. There are some states, like California, where public universities are less expensive because of higher state subsidies to state universities. There are community colleges in Pennsylvania offering associate degrees at much lower tuition. The community colleges role is to retrain the existing workforce. Community colleges receive funding from workforce development funds as they only offer associate degree programs (automotive technicians, computer technicians, practical nurses, laboratory technicians, dental hygienists, etc.).

Results. In the USA, as in many other countries, there exists a Competing for Well-prepared Motivated Students. Recruiting high-achieving motivated students is important for every academic program. Wellprepared students increase retention and graduation rates. Motivated incoming students have a better chance of becoming the type of graduates for which industry is looking. Highly employable graduates increase the employment rate and reputation of the program. A high employment rate combined with a good reputation of the program helps with student recruitment. Every academic program including Engineering programs has a vested interest in attracting the best possible high school graduates. A few strategies for accomplishing that are as follows:

1. Offer the students discounted tuition in the form of a scholarship. (Private universities have more flexible to do that. Public universities can use this method as well, but they are more limited.)

2. Offer dual enrollment opportunities. Dual enrollment opportunities allow junior and senior high school students to take introductory freshman-level classes at the university. To qualify for this opportunity, students need to maintain a designated grade-point average. University faculty select the courses suitable for dual enrollment opportunities. The Engineering program at The Pennsylvania State UniversityHazleton Campus selected a freshman course, Introduction to Engineering, as an appropriate course for a dual enrollment opportunity. Introduction to Engineering has been offered by the faculty at four different 
high schools within the Hazleton area. There was a design project incorporated in the course curriculum. The design project was teaching the students teamwork and lighting the fire by getting them excited about engineering. While taking a dual enrollment course(s), high school students are getting all the privileges of university students, for example, university email, identification card, transcript, access to the library system, career guidance, etc. After passing the dual enrollment course, high school students receive the grade on an official university transcript. Introduction to Engineering was the primary course taken by prospective engineering students. There were also other courses available to high school students as dual enrollment courses. One of the popular courses was Speech Communication which was also frequently chosen by prospective engineering students. Dual enrollment courses can be offered during the day at the high school location or during the evening at the university location. Dual enrollment students pay a discounted tuition and are getting a head start in the academic program. Dual enrollment opportunities are an effective method of attracting and recruiting motivated well-prepared high school students. Approximately $25 \%$ of the high school students taking dual enrollment classes at Penn State Hazleton enrol in the university's programs after high school graduation. Those are normally students that every program is trying to recruit because they are self-motivated.

3. Organize a regional research fair for high school students. The Engineering program at Penn State Hazleton (PSH) sponsors a science and engineering research fair as an annual event. High school students can do either a PowerPoint presentation, poster presentation or show-and-tell. During the research fair, high school students participate in a campus tour. Besides, they meet the Engineering faculty as well as some Engineering students. Every participant receives an award. The winner of the research fair receives a significant financial award which can only be applied toward tuition at The Pennsylvania State University. The regional research fair was a way to recruit well-prepared and dedicated students.

4. Collect and Maintain Statistical Data Related to Placement Rate of Program Graduates. All engineering programs at The Pennsylvania State University track the program graduates and collect data on how many students find employment in the engineering field within 3 months of graduation. Most private universities do the same thing. The university also collects data related to the salary of engineering graduates, especially the salary immediately after graduation. That statistical data is extremely helpful while discussing the program with prospective students and their family. Most parents of prospective students view the university program as an investment in their child's future. They want to know the return on that investment in the form of the salary after graduation as well as the employment rate. The statistical data related to employment is a highly effective method of promoting the program and attracting highquality incoming students.

5. Allow the High School Students to be a Guest in Some Engineering Classes. Periodically every academic program organizes an «open house» event (usually on Saturday) for prospective students. Many high school students and their families participate in the program. It is important from the perspective of students and their families to meet the faculty teaching in the program. Involving current students to participate in the open house is also extremely helpful. Many prospective students and their family appreciate the opportunity to meet with current students and hear their opinion about the program. Very often prospective candidates into the academic program appreciate the opportunity to sit on some of the engineering classes (or other classes). During the open house, a faculty member can invite prospective students to sit as a guest in some of the college classes. High school students and their families usually appreciate that gesture of the faculty. Allowing the high school students interested in the program to participate as a guest in some classes is a highly effective method of attracting energetic and well-prepared students.

6. Project Driven Curriculum (High Visibility Student Projects). Studying engineering is significantly enhanced by student involvement in the exciting state of the art projects. Exciting high visibility projects completed by engineering students at The Pennsylvania State University Hazleton Campus included: 2 
solar-powered cars, an experimental airplane, zero utility building, etc. Those projects were incorporated in some of the engineering classes. Education needs to be like «lighting a fire» and not «filling up a bucket». Interesting projects are doing that. They allow for enthusiasm and excitement among faculty and students. Enthusiasm is contagious and allows for a bond to be formed between faculty and students. It creates a sense of pride and accomplishment within students. Involving high school students in those projects is a highly effective method of attracting highly motivated and well-prepared students.

7. Establishment of an Entrepreneurial Center. Two years ago, an Entrepreneurial Center was established at The Pennsylvania State University Hazleton Campus. The Entrepreneurial Center is offering programs for university students, high school students, as well as the general public. Entrepreneurial Center offers evening courses related to the field of entrepreneurship and innovativeness. The establishment of the Entrepreneurial Center allows to better promote engineering and business program at The Pennsylvania State University. The academic programs became more visible to high school students as well as the general public. Engineering and business faculty are involved in the activity of the Entrepreneurial Center. This allows creating higher visibility for The Pennsylvania State University. It also allows creating higher visibility for engineering and business faculty. The faculty from The Pennsylvania State University is also involved in activities of the Cultural and Ethnic Integration Centers in Hazleton, PA. Cultural and Ethnic Interrogation Center is assisting immigrants coming to the area to become established and assimilated. Integration Center also helps with the educational needs of immigrant children. The engineering faculty was teaching evening programs entitled, «Engineering, a Roadmap to a Rewarding Career». This was an after-school program offered at the Integration Centers. Involvement of the engineering faculty with the Cultural and Ethnic Integration Center was also an effective method for attracting students to The Pennsylvania State University.

The summary of the strategies for promoting the Engineering program at The Pennsylvania State University (Hazleton Campus) is shown in Table 1. Those methods were identified based on the best and most effective practices applied at The Pennsylvania State University. Table 1 contains the assessment of the effectiveness of the individual methods based on the first-hand experience in administering the engineering program at the Hazleton Campus. The information provided in Table 1 is qualitative data.

Table 1. Effectiveness of different methods for promoting Engineering programs and attracting highly qualified students

\begin{tabular}{|c|c|c|}
\hline $\begin{array}{l}\text { Method of Promoting the } \\
\text { Program }\end{array}$ & $\begin{array}{l}\text { Effectiveness of the } \\
\text { Methods (based on } \\
\text { experience) }\end{array}$ & Comments \\
\hline $\begin{array}{l}\text { Offer students discounted tuition in } \\
\text { the form of scholarships (normally } \\
\text { for the first year of study) }\end{array}$ & Effective & Mostly at private universities \\
\hline Offer dual enrollment opportunities & Very effective & $\begin{array}{c}\text { Approximately } 25 \% \text { of dual enrollment } \\
\text { students enrolling in the engineering } \\
\text { program }\end{array}$ \\
\hline $\begin{array}{l}\text { Organize regional research fair for } \\
\text { high school students (offer } \\
\text { discounted tuition to the winner of } \\
\text { the research fair) }\end{array}$ & Very effective & $\begin{array}{c}\text { Bringing only a small amount of the best } \\
\text { students }\end{array}$ \\
\hline $\begin{array}{l}\text { Collect and maintain statistical data } \\
\text { related to the placement rate of } \\
\text { program graduates }\end{array}$ & Very effective & $\begin{array}{l}\text { A good employment rate with high } \\
\text { starting-salaries is } \\
\text { very convincing to prospective students } \\
\text { as well as their parent }\end{array}$ \\
\hline
\end{tabular}




\section{Continued Table 1}

\begin{tabular}{|c|c|c|}
\hline $\begin{array}{l}\text { Allow high school students to be a } \\
\text { guest in some Engineering classes }\end{array}$ & Effective & $\begin{array}{l}\text { Attracts undecided students; } \\
\text { There is no cost to the university }\end{array}$ \\
\hline $\begin{array}{l}\text { Project-driven curriculum } \\
\text { (High-visibility student projects) }\end{array}$ & Very effective & $\begin{array}{l}\text { Increases retentions in the academic } \\
\text { program. Helps with the recruitment of } \\
\text { new incoming students }\end{array}$ \\
\hline Establish an entrepreneurial center & Effective & $\begin{array}{l}\text { Attracts students into the Engineering } \\
\text { program as well as the Business } \\
\text { program. Sparks entrepreneurial interest } \\
\text { among students }\end{array}$ \\
\hline
\end{tabular}

Sources: developed by the authors.

Conclusions. Summarizing the above considerations, it should be pointed out that universities, similarly to economic entities, must now use marketing instruments to effectively compete on the educational market. Universities should apply comprehensive solutions based on a strategic approach in marketing activities and skillfully adapt previously developed solutions used in enterprises or institutions (cf. e.g. Pimonenko et al., 2019; Kuzior et al., 2019a; Kwilinski, 2018). Universities should use all available marketing mix instruments, including relationship marketing, along with skilful communication of the educational offer on the educational market. An important element is adapting the offer to the needs of the evolving labour market and offering products and services that not only focus on current needs but offering students a range of competencies that will allow them to effectively find employment in the future, in the dynamically developing technological reality based on innovative solutions of cognitive technologies and artificial intelligence (Kuzior et al., 2019b; Kwilinski et al., 2019; Kuzior et al., 2019c; Kwilinski and Kuzior, 2020). One should also not forget about the humanistic aspect of engineering education (Kuzior et al., 2019b). The solutions adopted at Penn State Hazleton require a more comprehensive approach. An approach based solely on What are we selling? What is the price for which we are selling? is no longer sufficient. An important element is a focus on the quality of education, so that universities, in pursuit of the «client», do not give up intellectualizing education (Antczak, 2011) and, in line with A. Einstein's message, that a university graduate should leave its walls as a harmonious personality, and not only as a specialist in a given field.

Author Contributions: A. K. - conceptualisation and literature review; A. K., M. G., W. G. - research works; A. K., M. G., W. G. - the methodical approach; A. K., M. G., W. G. - writing original draft reparation; A. K. - writing-review and editing. All authors have read and approved the final manuscript.

\section{References}

Antczak, B. (2011). Usługi edukacyjne-rynek taki sam jak inne?. Wydawnictwo Wyższej Szkoły Gospodarki Euroregionalnej im. Alcide De Gasperi. [Google Scholar]

Bartels, R. (1988). The History of Marketing Thought, published 3. Gorsuch Scarisbrick Pub, New York.

Bolat, E., \& O'Sullivan, H. (2017). Radicalising the marketing of higher education: learning from student-generated social media data. Journal of Marketing Management, 33(9-10), 742-763. [Google Scholar] [CrossRef]

Brkanlic, S., Sanchez-García, J., Esteve, E. B., Brkic, I., Ciric, M., Tatarski, J., ... \& Petrovic, M. (2020). Marketing Mix Instruments as Factors of Improvement of Students' Satisfaction in Higher Education Institutions in Republic of Serbia and Spain. Sustainability, 12(18), 7802. [Google Scholar] [CrossRef]

Brownlie, D., \& Saren, M. (1992). The four Ps of the marketing concept: prescriptive, polemical, permanent and problematical. European Journal of Marketing, 26(4), 34-47. [Google Scholar] [CrossRef]

Celoch, A. (2015). Rola marketingowego zarządzania szkoła wyższą w aspekcie zmian na rynku usług edukacyjnych. Annales Universitatis Mariae Curie-Skłodowska, Sectio H Oeconomia, 49(1), 35-42. [Google Scholar]

Chawla, M. (2013). Customers (Students) perceptions about 7Ps of Higher Education Marketing Mix. Asian Journal of Multidisciplinary Studies, 1(5), 107. [Google Scholar] 
Drucker, P. F. (1954). The Practice of Management-New York: Haper e Row.

Education Benefits and Financial Aid. (2020). Retrievef from [Link]

Fajčíkova, A., \& Urbancova, H. (2019). Factors Influencing Students' Motivation to Seek Higher Education-A Case Study at a State University in the Czech Republic. Sustainability, 11(17), 4699. [Google Scholar] [CrossRef]

Fantauzzi, C., Frondizi, R., Colasanti, N., \& Fiorani, G. (2019). Creating value in the entrepreneurial university: marketization and merchandising strategies. Administrative Sciences, 9(4), 82. [Google Scholar] [CrossRef]

Friedman, Z. (2020). Student Loan Debt Statistics in 2020: A Record \$1.6 Trillion. Retrieved from [Link]

Fullerton, R. A. (1988). How modern is modern marketing? Marketing's evolution and the myth of the "Production Era". Journal of marketing, 52(1), 108-125. [Google Scholar] [CrossRef]

Glazar, O., \& Strielkowski, W. (2009). Turkey and the European Union: possible incidence of the EU accession on migration flows. Prague Economic Papers, 19(3), 218-235. [Google Scholar] [CrossRef]

Girchenko, T. D., Panchenko, O.V. (2020). Research on the practical aspects of the providing efficiency of marketing communications' bank. Financial and credit activity-problems of theory and practice, 3. P. 13-22. [CrossRef]

Guilbault, M. (2016). Students as customers in higher education: reframing the debate. Journal of Marketing for Higher Education, 26(2), 132-142. [Google Scholar] [CrossRef]

Guilbault, M. (2018). Students as customers in higher education: The (controversial) debate needs to end. Journal of retailing and consumer services, 40, 295-298. [Google Scholar] [CrossRef]

Hagerty, J. E. (1936). Experiences of an early marketing teacher. Journal of Marketing, 1(1), 20-27. [Google Scholar] [CrossRef] Hayes, T. (2007). Delphi study of the future of marketing of higher education. Joumal of business research, 60(9), 927-931. [Google Scholar] [CrossRef]

Helgesen, $\varnothing$. (2008). Marketing for higher education: A relationship marketing approach. Journal of marketing for higher education, 18(1), 50-78. [Google Scholar] [CrossRef]

Information for Military Families and Veteransю (2020). Retrieved from [Link

Ivy, J. (2008). A new higher education marketing mix: the 7Ps for MBA marketing. International Journal of Educational Management, 22(4), 288-299. [Google Scholar] [CrossRef]

James, M., \& Derrick, G. (2019). Export marketing in higher education: An international comparison [EarlyCite]. Journal of International Education in Business, (2). [Google Scholar] [CrossRef]

Knight, E. (2019). Massification, Marketisation and Loss of Differentiation in Pre-Entry Marketing Materials in UK Higher Education. Social Sciences, 8(11), 304. [Google Scholar] [CrossRef]

Kozielski, R. (2013). Ewolucja marketingu - wymiar historyczny i naukowy. Retrieved from [Link]

Kustin, R. A. (2004). Marketing mix standardization: a cross cultural study of four countries. International Business Review,

13(5), 637-649. [Google Scholar] [CrossRef]

Kuzior, A. (2007). Społeczna odpowiedzialnośc menadŜerow i społeczna odpowiedzialnośc przedsiębiorstw-recepcja poglądow

Petera F. Druckera, w: Świadectwo Petera Druckera, red. Sobieraj I., Broda J., Rąb J., Zabrze, 97-109.

Kuzior, A. (2010). Polskie i niemieckie doświadczenia w projektowaniu i wdrażaniu zrownoważonego rozwoju. Problemy Ekorozwoju, 5, 81-89. [Google Scholar]

Kuzior, A., Grebski W. and Lyulyov O. (2019b). Rola etyki w kształceniu inżynierow. Etyka Biznesu i Zrownoważony Rozwoj, 1 ,

16-28. Retrieved from [Link]

Kuzior, A., Kwilinski, A., \& Tkachenko, V. (2019c). Sustainable development of organizations based on the combinatorial model of artificial intelligence. Entrepreneurship and Sustainability Issues, 7(2), 1353. [Google Scholar] [CrossRef] Kuzior, A., Sobotka, B. Filipenko, \& Kuzior, P. (2019a). Marketing communications of administrative organs of local governance and local communityweb of science. Marketing and Management of Innovations, 2, 314-325. [Google Scholar] [CrossRef]

Kuznyetsova, A. Y., \& Klishchuk, O. V. (2017). Theoretical conception of price stability targeting arrangement: investigation of basic principles of implementation monetary regime. Financial and credit activity: problems of theory and practice, 2(23), 388-396. [Google Scholar] [CrossRef]

Kuznetsova A., Kalynets K., Kozmuk N. (2018). Innovative management in global financial csr governance. Marketing and management of innovations, 2. P. 262-269. [CrossRef]

Kwilinski, A. (2018). Mechanism of formation of industrial enterprise development strategy in the information economy. Virtual Economics, 1(1), 7-25. [Google Scholar] [CrossRef]

Kwilinski, A., \& Kuzior, A. (2020). Cognitive technologies in the management and formation of directions of the priority development of industrial enterprises. Management Systems in Production Engineering, 28(2), 133-138. [Google Scholar] [CrossRef] Kwilinski, A., Tkachenko, V., \& Kuzior, A. (2019). Transparent cognitive technologies to ensure sustainable society development. Journal of Security \& Sustainability Issues, 9(2). [Google Scholar] [CrossRef]

Lopes, B., Silva, P., Melo, A. I., Brito, E., Paiva Dias, G., \& Costa, M. (2019). The «Lunar Side»of the Story: Exploring the Sustainability of Curricular Internships in Higher Education. Sustainability, 11(21), 5879. [Google Scholar] [CrossRef] Matejun, M. (2011). Metoda studium przypadku w pracach badawczych młodych naukowcow z zakresu nauk o zarzadzaniu. Marketing i Zarządzanie, (19), 203-213. [Google Scholar]

Mazurek, G., Korzyński, P., \& Gorska, A. (2019). Social Media in the Marketing of Higher Education Institutions in Poland: Preliminary Empirical Studies. Entrepreneurial Business and Economics Review, 7(1), 117-133. [Google Scholar] [CrossRef] 
Ndofirepi, E., Farinloye, T. \& Mogaji, E. (2020). Marketing mix in a heterogenous higher education market: a case of Africa. In: Mogaji, E. , Maringe, F. and Hinson, R. (eds.) Understanding the Higher Education Market in Africa. Routledge Studies in Marketing. Routledge. [Google Scholar]

Nureev, R., Volchik, V., \& Strielkowski, W. (2020). Neoliberal Reforms in Higher Education and the Import of Institutions. Social Sciences, 9(5), 79. [Google Scholar] [CrossRef]

Pabian, A. (2008). Student jako beneficjent działań promocyjnych szkoł wyższych. Marketing i Rynek, (8), 31-37. [Google Scholar]

Penar, D., \& Szczepańska-Woszczyna, K. (2011). Marka szkoły wyższej-w poszukiwaniu przewagi konkurencyjnej. Marketing w szkole wyższej, Poznań: Wyd. WSB w Poznaniu, 257-268. [Link]

Penn State News. (2020). Penn State Planning to Freeze 2020-21 Tuition to Help Ease COVID-19 Hardships. Retrieved from

Penn State Tuition and Costs - Undergraduate Admissions. Retrieved from [Link]

Pimonenko, T., Liuliov, O., \& Us, Y. (2019). Marketing strategies of green investments: basic concepts and specific features. Herald of Ternopil National Economic University, 1(91), 177-185. [Google Scholar] [CrossRef]

Rosmala, D. (2012). Study of social networking usage in higher education environment. Procedia-Social and Behavioral Sciences, 67, 156-166. [Google Scholar] [CrossRef]

Simionescu, M., Strielkowski, W., \& Kalyugina, S. (2017). The impact of Brexit on labour migration and labour markets in the United Kingdom and the EU. Terra Economicus, 15(1), 148-156. [Google Scholar] [CrossRef]

Smørvik, K. K., \& Vespestad, M. K. (2020). Bridging marketing and higher education: resource integration, co-creation and student learning. Journal of Marketing for Higher Education, 30(2), 256-270. [Google Scholar] [CrossRef]

Strielkowski, W., \& Höschle, F. (2016). Evidence for economic convergence in the EU: The analysis of past EU enlargements. Technological and Economic Development of Economy, 22(4), 617-630. [Google Scholar] [CrossRef]

Trullas, I., Simo, P., Fusalba, O. R., Fito, A., \& Sallan, J. M. (2018). Student-perceived organizational support and perceived employability in the marketing of higher education. Journal of Marketing for Higher Education, 28(2), 266-281. [Google Scholar] [CrossRef]

VA Education and Training Benefits. (2020) Retrieved from [Link

Webster, F. E. (2002). Marketing management in changing times. Marketing management, 11(1), 18. [Google Scholar]

Weld, L. D. H. (1915). Studies in the marketing of farm products (No. 4-6). Bulletin of the University of Minnesota. [Google Scholar]

Wojcik, P. (2013). Znaczenie studium przypadku jako metody badawczej w naukach o zarzadzaniu. E-mentor, 48(1), 17-22. [Google Scholar]

Олександра Кузьор, Ph.D., Сілезійський технологічний університет, Польща

Міхалена Гребські, Ph.D., Університет Колорадо Меса, США

Вес Гребські, Ph.D., Університет штату Пенсильванія, США

Маркетинг освітніх програм: на прикладі інженерних спеціальностей

У рамках даної статті систематизовано аргументи та контраргументи щодо необхідності оновлення навчальних програм у закладах вищої освіти. Автори зазначено, що традиційні навчальні програми є застарілими, негнучкими та непривабливими для здобувачів освіти, тоді як університети зацікавлені у найкращих та високомотивованих учнях середньої школи. Сучасна система освіти може розглядатись як окрема бізнес-структура, яка надає на ринку освітні послуги. Наразі спільнотою вища освіта розглядається як інвестиційний проєкт, еконімічні вигоди якого проявляються у вигляді високооплачуваної роботи. Таким чином, на ринку освітніх послуг відбувається зростання рівня конкуренції як зі сторони приватних університетів, так I між державними університетами. Виходячи 3 вищезазначеного, головною метою цього дослідження $є$ розроблення ефективної маркетингової стратегї навчальних програм, які мають бути адаптованими до мінливих умов зовнішнього середовища. Авторами проаналізовано маркетингові інструменти просування освітніх послуг закладами вищої освіти на прикладі освітньої програми з інженерії Пенсильванського державного університету Хейзлтон (США), який $є$ потужним конкурентом низки приватних університетів у США. У рамках дослідження авторами проведено ситуаційний аналіз маркетингової та комунікаційної стратегій Пенсильванського державного університету Хейзлтон. Отримані результати засвідчили про необхідність застосування маркетингової концепції «7Р». Авторами наголошено, що при промоції освітніх програм необхідним та побудови його бренду $є$ врахування ефективності каналів комунікації, фідбеків про заклад вищої освіти. Це дозволить їм відповідати вимогам стрімкого глобального розвитку та змінам на ринку праці, забезпечуючи високу якість освітніх послуг за студентоцентрованого підходу. За отриманими результатами дослідження авторами сформовано низку рекомендацій та пропозицій, які можуть бути використані у діяльності приватних та держаних закладів вищої освіти.

Ключові слова: вища освіта, маркетингові комунікації, маркетинговий мікс, маркетингова стратегія, маркетинг взаємодій, маркетинг послуг. 